\title{
Particulate Matter from the Road Surface Abrasion as a Problem of Non-Exhaust Emission Control
}

\author{
Magdalena Penkała ${ }^{1}$, Paweł Ogrodnik ${ }^{2}$ and Wioletta Rogula-Kozłowska ${ }^{2,3, *}$ \\ 1 The State School of Higher Education, 54 Pocztowa St., 22-100 Chełm, Poland; mmagdapenkala@gmail.com \\ 2 The Main School of Fire Service, Faculty of Fire Safety Engineering, 52/54 Słowackiego St., 01-629 Warsaw, \\ Poland; pogrodnik@sgsp.edu.pl \\ 3 Institute of Environmental Engineering, Polish Academy of Sciences, 34 M. Skłodowskiej-Curie St., \\ 41-819 Zabrze, Poland \\ * Correspondence: wrogula@sgsp.edu.pl or wioletta.rogula-kozlowska@ipis.zabrze.pl; Tel.: +48-225-617-553
}

Received: 27 October 2017; Accepted: 5 January 2018; Published: 7 January 2018

\begin{abstract}
Along with house heating and industry, emissions from road traffic (exhaust and tire, brake, car body or road surface abrasions) are one of the primary sources of particulate matter (PM) in the atmosphere in urban areas. Though numerous regulations and vehicle-control mechanisms have led to a significant decline of PM emissions from vehicle exhaust gases, other sources of PM remain related to road and car abrasion are responsible for non-exhaust emissions. Quantifying these emissions is a hard problem in both laboratory and field conditions. First, we must recognize the physicochemical properties of the PM that is emitted by various non-exhaust sources. In this paper, we underline the problem of information accessibility with regards to the properties and qualities of PM from non-exhaust sources. We also indicate why scarce information is available in order to find the possible solution to this ongoing issue.
\end{abstract}

Keywords: ambient particulate matter; street dust; exhaust vs. non-exhaust emission; heavy metals; health hazard

\section{Introduction}

Road traffic emissions caused by both exhaust and non-exhaust sources contribute significantly to the particulate matter (PM) concentration in an urban atmosphere [1-22]. Additionally, very fine particles that are emitted through various road traffic-related processes (e.g., brake wear), can penetrate the human organs [23-25]. A knowledge of physicochemical properties and PM sources is crucial for determining the environmental effects of PM [26-30].

Most of the PM mass, where PM is created by the abrasion of a car body, tires, or a road surface, is composed of particles with diameter ranging between 1 and $10 \mu \mathrm{m}$ [9,31-35]. For this reason, coarse PM (fraction of atmospheric particles with an aerodynamic diameter in the 2.5-10 $\mu \mathrm{m}$ range; coarse PM) usually makes up most of the PM mass close to crossroads. In Switzerland, the $\mathrm{PM}_{10}$ in an urban street canyon may result from brake-disc abrasion (21\%), resuspension (38\%), or exhaust emissions (41\%), while the $\mathrm{PM}_{10}$ found along a freeway consists mainly of resuspension dust (56\%) and particles emitted by exhaust emissions (41\%) [36]. Both the $\mathrm{PM}_{2.5}$ (fraction of atmospheric particles with an aerodynamic diameter not exceeding $2.5 \mu \mathrm{m}$; fine PM) mass share of PM and the ambient concentration of $\mathrm{PM}_{2.5}$ in the vicinities of roads are strongly affected by exhaust emissions than by non-exhaust emissions $[11,12,20,37]$. When compared to $\mathrm{PM}_{2.5}$ from other areas, the effect of car fume emissions can mainly be seen in an increase in soot and some organic compounds in the $\mathrm{PM}_{2.5}$ mass $[3,4,6,11-13,20,21]$.

Most of the PM mass from non-exhaust emissions, regardless of the type of traffic site (road, crossroad, or highway), is made of resuspension dust. This is a mixture of particles derived from 
car body abrasions, brake pads, brake discs, tires, and road surface; and, on the other hand, from soil and particle elements that have settled on the surface of the road (originating from sources other than road traffic) $[9,11,12,33,34]$. These particles are usually enriched with various organic compounds $[15,20-22,38]$. In order to reduce the impact of resuspension dust on air quality in urban areas, appropriate methods are employed. For instance, for the prevention of PM resuspension, hardening, unpaved roads may be exposed to chemical-binder agents, as well as water-spraying in dry periods [39-41]. Frequently cleaning the surface via washing and sweeping is a practice used for paved roads. The reduction of PM emissions can also be achieved by limiting both vehicle speed and mass or by using a noise barrier on the roads (e.g., a green-wall sound barrier). The effectiveness of applied methods varies depending the frequency at which particles are removed and local meteorological conditions. The reduction of resuspension dust can reach an efficiency of up to $90 \%$ [39-41].

In this work, we demonstrate that the isolation of particles that only results from road surface abrasion from resuspension dust particles is particularly difficult. However, this step is necessary for the proper quantification of non-exhaust emissions in a particular area.

\section{Non-Exhaust PM Emissions and Their Relation to Air Pollution in the Vicinity of Roads and Crossroads}

Non-exhaust sources of PM include:

- Tires: PM from tire abrasions comprises among others, metals: $\mathrm{Cd}, \mathrm{Cu}, \mathrm{Pb}, \mathrm{Zn}[33,42-44]$ and organic compounds such as natural rubber copolymer, organotin compounds, and soot [9].

- Brakes: PM from brake-pad and brake-disc abrasion consists of metals: $\mathrm{Zn}, \mathrm{Cu}, \mathrm{Ti}, \mathrm{Fe}, \mathrm{Cu}$, $\mathrm{Pb}[33,45-51]$ and other specific compounds such as sulfate silicate, barium sulfate, carbon fibers, and graphite $[9,52,53]$.

- The car body: some particles from the vehicle's consumable parts are released into the air; they may contain small amounts of metal like $\mathrm{Zn}$ and Fe [35].

- The road surface: PM from road-surface erosion containing characteristic compounds such as bitumen, cement, and resins [33].

- Paints: the composition of the paint intended for road-surface painting suggests that PM from this source may contain $\mathrm{Pb}$ and $\mathrm{Ti}$ [54].

It is clear that the level of PM air pollution resulting from non-exhaust sources at roads is dependent on traffic, speed as well as the shape and system of the road interchanges.

Released particles are permanently mixed coming from combustion, industry, exhaust emissions and soil [9,55-59]. PM from anthropogenic sources include particles from so-called municipal emissions (mainly soot, organic matter, and inorganic salts resulting from the combustion of coal and biomass in domestic furnaces, local coal-fired boiler plants, or heat plants [20,60-62]) and from industrial emissions (mainly fine particles enriched in heavy metals or persistent organic pollutants [63-68]). In addition, particles of salt, sand (coarse PM), or a mixture of both are released into the urban atmosphere, especially during the winter season $[9,25,35,40,69]$. In built-up areas, e.g., city centers, compact residential and service buildings close to traffic arteries significantly reduce air-mass exchange; this results in the accumulation of PM in the ground atmosphere layer $[11,12,19,55,56]$. The non-exhaust-based particles and particles from other sources creates complex chemical PM mixtures near traffic sites [11-13,21,33,35].

PM-bound elements, including some toxic metals, are subjected to similar phenomena. The ambient concentration of PM-bound elements in the areas affected by road-traffic emissions also depends on the traffic intensity, the vehicle-fleet characteristics car type and speed, the type of road surface, the road-cleaning intensity, and the concentration of PM components in the so-called urban background [70-73]. Given that, it is easy to imagine the difficulty in quantitatively dividing PM-bound elements, located in urban sites that are influenced by traffic emissions, into specific source groups. 
Meanwhile, it is extremely important to clearly distribute these element mixtures as such a distribution constitutes the first and most important step in programs and scenarios that aim to reduce PM concentrations in areas characterized by high ambient concentrations of PM. The physical removal of elements from road and street surfaces via washing and sweeping does not sufficiently limit human exposure to PM resulting from traffic emission [55]. The complex process of overlapping the so-called urban background onto road traffic pollutants, along with the associated physical changes and chemical reactions, lead to the conclusion that PM close to roads may be much more toxic or may have a higher carcinogenic potential than PM outside such areas [11,12,20,70,74-77].

Using data derived from several European cities, Querol et al. [78] estimated that PM emissions from road traffic was roughly distributed between exhaust and non-exhaust emission sources. Similarly, in Berlin, Lenschow et al. [79] showed that in areas where air quality is determined by road traffic emissions (on urban roads) half of the $\mathrm{PM}_{10}$ mass comes from non-exhaust sources. Studies conducted in Poland in the last decade clearly showed that PM emissions from non-exhaust sources are significantly more present than PM from exhaust emissions at roads and crossroads [11-13,37]. This contribution was apparent even during smog episodes, when emissions from the combustion of fossil fuels in domestic furnaces determined the air quality in the city of Zabrze [19].

In this respect, the contribution of PM emissions from non-exhaust sources is large, certainly much larger than was previously thought. Nevertheless, we still lack detailed information [75,80-83]. Data and rationales are missing for the reliable subdivision of PM emissions into those from exhaust vs. those from non-exhaust sources, for the separation of road-traffic related PM from PM related to other sources [20,62], and, above all, for the segmentation of PM generally derived from non-exhaust sources into specific source groups (tire abrasion, brakes, road surface, etc.).

The simplest way of subdividing road-traffic related PM (though this does not apply to PM-bound elements) into specific sources is to assign a particular PM size, or rather particles belonging to a corresponding size range (i.e., size fractions), to specific sources; these compartments are characterized by so-called lower and upper limit cut-off diameters [84-86]. Many research papers are devoted to investigating the fractional composition of particles related to specific road-traffic sources. In general we can say that non-exhaust emissions mainly include coarse PM, while PM from exhaust emissions consists of fine particles belonging to $\mathrm{PM}_{2.5}$ [34,87-89]. If we consider size when examining the distribution of PM particles in non-exhaust emission sources, particles of worn road surfaces usually belong to the coarse PM, while particles from the tires and brake discs are both coarse and fine [90]. In northern European countries, where various methods are used during winter to prevent icing on roads, and winter tires and snow chains are commonly used, $\mathrm{PM}_{2.5-10}$ accounts for up to $90 \%$ of PM in atmospheric air [73,91]. However, brake discs were selected to be examined, as their usage is the most detailed, in terms of the amounts of emitted particles (emission factors) and their properties $[9,33,55,80,87,92,93]$. The identification and quantification of PM from other non-exhaust sources are much more difficult. The list of published papers describing the PM emission factors and properties of PM emitted by these sources is therefore much shorter. For example, it was shown that particles with a diameter ranging from several hundred nanometers to several tens of micrometers are produced during the brake-lining and disc-abrasion processes [33]. On the other hand, there are scientific reports showing that non-exhaust emissions (including brake wear) also produce nanoparticles [23-25]. The size of emitted particles depends primarily on the physical properties, shape and structure, and the chemical composition of the abrasive/erosion material, on the nature, value, and complexity of the forces acting on the material, and on the temporal and spatial variability of these parameters [94]. It should be clearly stated that the above-mentioned assignment of specific PM emission sources to appropriate size ranges is contractual and far from sufficient for separating PM into specific emission sources.

Rather than using particle-size distribution, a far more reliable way of achieving this separation involves examining the chemical composition (relatively elemental composition) of PM particles and comparing it with the chemical compositions of particles directly emitted by each of the individual 
emission sources [52,95-97]. These were widely described as so-called elemental PM profiles from both exhaust and non-exhaust emissions. Prior to the introduction of a law prohibiting the use of leaded petrol, $\mathrm{Pb}$ was a PM marker related to the combustion of gasoline in engines [98]. PM markers from working catalytic converters are metals from the platinum group such as $\mathrm{Rh}$ and $\mathrm{Pt}$ [99-101]. Zn, $\mathrm{Cu}$, and Ti in urban air are often related to brake-pad erosion [33,47]; particles from brake-disc wear are typically characterized by $\mathrm{Fe}, \mathrm{Cu}, \mathrm{Pb}$, and $\mathrm{Zn}[33,45,46,48-51]$. To identify PM from tire abrasion, $\mathrm{Cd}, \mathrm{Cu}, \mathrm{Pb}$, and $\mathrm{Zn}$ may be monitored, among others [33,42]. Occasionally, metals such as Fe and $\mathrm{Zn}$ are also linked to the corrosion of car-body parts [35].

The most difficult data to find involves the elemental composition of PM arising from the abrasion of road surfaces. The root of the problem lies in the nomenclature given to the material emitted directly by the worn road surface and to the material laid on road and then resuspended. Often, the same particles are attributed to several sources [20,33,62,102].

Fauser (1999) identified asphaltenes and maltenes as potential tracers for road-surface wear [103]. Kupiainen et al. (2003) used the presence of hornblende as a tracer for PM derived from road-surface wear [44]. However, this was in a controlled laboratory test, where the road-surface material constituted the only possible source of this mineral. Polycyclic aromatic hydrocarbons (PAHs) have been identified in bitumen samples, although the concentrations of individual PAHs are very low due to their removal during the distillation process [104]. The lack of a PAH compound unique to bitumen makes such compounds unusable as marker species for road-surface wear [105]. A number of metals have been detected in road bitumen samples including $\mathrm{V}, \mathrm{Ni}, \mathrm{Fe}, \mathrm{Mg}$, and $\mathrm{Ca}[48,106]$. However, a comparison of concentrations in road bitumen with raw bitumen samples revealed much higher concentrations of these metals in the former, indicating that the road-surface material had incorporated these elements from other sources [48]. In conclusion, it may prove very difficult to identify suitable tracer species for road-surface wear [33].

It seems that we lack reliable information on the PM or dust emitted by different road surfaces' erosion processes, and this constitutes a significant gap in the current state of knowledge of non-exhaust sources of road traffic emissions. Such information should include: (i) the fractional composition data (ii) the chemical or elemental composition of the PM / dust particles emitted during the erosion of different road surfaces.

\section{Types of Road Surfaces and Their Importance in the Non-Exhaust Emissions of PM}

Road pavements can be classified by their construction, deformability, load-bearing capacity, and material types used for the driving layer. Due to the surfaces' deformability, they can be divided as follows:

- susceptible: surfaces with a structure that deforms plastically under the influence of loads (sett, gravel, and bitumen surfaces located on susceptible substrates).

- semi-rigid: asphalt surfaces with a foundation made of concrete, lean concrete, aggregates, or stabilized soils.

- rigid: surfaces with a structure that deforms elastically under a load (cement concrete surfaces) [107-109].

The surface's wearing course can be made of the following mineral-asphalt mixtures:

- $\quad$ asphalt concrete (AC), stone mastic asphalt (SMA), mastic asphalt (MA), very thin-layered asphalt concrete (BBTM), and porous asphalt (PA) [110].

A topcoat made of cement concrete can be made in the form of roofed, doweled and anchored, or reinforced plates [111].

Even without any measurements and tests, it is generally recognized that vehicles moving on unpaved roads will generate a significantly greater amount of PM than paved or hardened roads. In particular, the generation of high levels of dust is linked to ground and gravel made of crushed debris and slag roads. In comparison to paved roads (stone-paved, concrete, or asphalt roads), the top 
layers of unpaved roads (especially particles with a small diameter) move, as a result of the friction of the wheels on the surface. Loose surface grains move under the mechanical stress of the wheels. The free material is lifted under the effect of the vacuum that is generated by the tire surface breaking off from the road surface. Equally, dust is raised from the road surface onto the wheel tread $[35,112,113]$. However, concerning the impact on air quality unpaved roads are less interesting than paved roads. First of all, the chemical composition of the PM or dust particles emitted by unpaved roads is well known, and it is equal to the composition of soil in the case of forests for example, or to gravel and sand in the case of gravel roads for example [114]. Consequently, in terms of chemical properties, the PM or dust emitted during the erosion of such roads is almost identical, in a given area, with soil particles or the top soil layer [33]. The content in such particles may depend only on the degree of contamination of the soil or sand. Therefore, it basically depends on the road localization [115]. Road dust and roadside soil often contain metals, including $\mathrm{Pb}, \mathrm{Cu}, \mathrm{Cd}$, and $\mathrm{Zn}$, indicative of contamination by road traffic emissions. Through the calculation of crustal enrichment factors (CEFs), the presence of contaminants in road dust and roadside soil provides a means by which particles arising from anthropogenic sources can be separated from natural or crustal sources [11,12]. However, comparing the contribution of road-surface wear to that of resuspended road dust will require the development of an alternative approach [33]. Additionally, unpaved roads are usually located outside urban centers, in less-populated areas such as villages, small municipalities, and around small housing estates (access roads). They are therefore of little importance when compared to the state of air quality in city centers, where PM concentrations matter to authorities and sanitary services. Furthermore, it seems that the impact of unpaved-road emissions on the quality of atmospheric air is difficult and, almost impossible to estimate due to the high variability in time [116].

This is not the case for paved roads. First of all, they are built from mixes that are produced through strictly-defined processes. Their composition must therefore differ from the composition of natural components such as soil or sand. In addition, they are made of road surfaces where vehicles are able to move at high speeds, and varied with types ranging from compact passenger cars to several-ton trucks on highways. It seems, therefore, that the size of PM or dust particles generated during erosion may fit within a wide range Their composition determined by the structure of building material's original mixture may also vary depending on the place (road age, renovations, degree of wear, etc.) [116,117].

Most paved road surfaces have the same base: a mixture of aggregates such as bitumen or cement with different grain sizes, and modifiers such as fillers and binders [35]. The choice and proportions of the ingredients dictate the exact differences in chemical composition of mixtures made for the production of road surfaces [118]. Road surfaces can be widely classified as being made of either concrete or asphalt. Asphalt consists mainly ( $\sim 95 \%$ of the mass) of mineral aggregates and various geological materials [93]. Its remaining content is mostly bituminous binder, modified by the addition of fillers and adhesives [106]. The bitumen contains many thousands of high-molecular-weight organic compounds (about 500-50,000 u), most of which are aliphatic and aromatic hydrocarbons [33].

As a result of increasing requirements of road surfaces' strength parameters, the continuous growth in their heavy traffic load, and the fact that extreme weather conditions occur at various latitudes, diverse types of modifiers are introduced into the bitumen-bonding compound or asphalt mix. This aims to improve both the properties of the road surface and the bond between the binder and mineral components. Adhesives are joined to aggregates using fillers and reinforcing fibers such as glass, fly ash, and shredded used tires $[33,119]$. This solution is increasingly prevalent due to problems related to the utilization of tires. Polymers, epoxy resins, and low-carbon steel are used as modifiers, while sulfur is used to increase the rigidity of the binder [33].

Concrete pavements are made of mineral aggregates, sand, and cement [35]. The literature provides little information on the chemical composition of concretes that are used to produce roads and on the dust emitted by such surfaces. This is related to the fact that there are many ways of choosing the composition and proportion of materials used to make a concrete mix. As a consequence there is 
no universal molecular formula for the concrete mix and therefore for particles emitted during the erosion of such road surfaces [33].

When concrete pavements are made, many different additives affect the strength of the material when they are introduced into the mix. Due to the fact that the structures are designed for a maximum period of 30 years, old concrete surfaces are significantly damaged and therefore not always adapted to heavy traffic and vehicle loads. This may result in emissions of PM and dust into the atmosphere, not only from the base-surface components released during the vehicle's movement but also from the processes and materials used for the surfaces' temporary repairs [120].

In order to promote the use of cement and concrete in the transport infrastructure, the non-profit European Concrete Paving Association (EUPAVE) was established in 2007. Their mission is to advocate and enable the wider use of cement and concrete applications in European transport infrastructures. They are involved in engagement with EU, national, and local decision makers, disseminating technical know-how, and presenting the benefits of using this material. According to EUPAVE, the use of cement and concrete in road-building implements a circular economy. Considering the hierarchy of waste management, in accordance with the European Commission's recommendations (prevention, reuse, recycling, recovery, and utilization), it seems obvious that construction using concrete, adheres to these principles. Concrete pavements have always been valued for their durability and low-maintenance costs, which are simple ways of obtaining ecological benefits [120].

Surface type also determines the wear of vehicles that move on it [35] The volume of dust emissions from used car tires in Britain in 1996 was $5.3 \times 10^{7} \mathrm{~kg}$, while in Japan it was $2.1 \times 10^{8} \mathrm{~kg}$ in 2001. Within a year, Germany's emissions range between 55 and $657 \mathrm{~kg} \cdot \mathrm{km}^{-1}$, depending on the type of road [121]. The asphalt surface causes less tire abrasion than concrete surfaces. In Arizona (in the United States), PM emissions are 1.4 to 2 times lower for asphalt roads than for concrete roads $[9,122]$. However, it is important to note what type of tires are used. Numerous studies have shown that winter tires generate much more dust, and this is mainly due to greater friction on the ground compared to their summer equivalents $[9,35,123-126]$. Furthermore, the use of metal constructions on tires, in the form of pins or chains, influences an increase in the level of road-surface abrasion $[9,44,127]$. In Sweden, studded tires are approved for use from October to April. The emission factor for $\mathrm{PM}_{10}$ from tire abrasion close to roads and junctions is clearly higher during this period than in other months [127].

Finally, the emission of particulate matter by road-surface abrasion is difficult to isolate in PM and dust tests in the field, and such test, which aim to define its characteristics, are therefore performed under controlled laboratory conditions $[36,44,125,128,129]$. In many countries, practically no road with a wearing course of cement-based concrete existed until the second half of the 20th century. When this technology was reintroduced in the mid-1990s, there were many new modifications in the production of concrete. For example, some special additives, when introduced into the mix (e.g., silica), affect the surface strength. Because the surfaces are designed to last for about 30 years, there is now a noticeable increase in damaged old concrete surfaces, which are not always adapted to today's increase in traffic and vehicle loads. This can cause significant emissions of PM or dust into the atmosphere from both base-surface elements released during vehicle movement and materials used for the emergency repair of these surfaces [119].

\section{Conclusions}

Current research shows that direct road-surface abrasion is of minor importance when the road is undamaged and that emissions of PM from direct road-surface abrasion are then significantly lower than emissions from other sources of road dust like abrasion of car body, brakes or tires [36,44,125,128-130]. Nevertheless, data on this subject is clearly lacking. This scarcity concerns both the availability of data on PM/dust emissions from road-surface abrasion in various places, and studies on PM/dust emission factors and related elements from different types of road surfaces as current research were restricted to asphalt surface only. The return to the technology of road construction and renovation with concrete in recent years is more challenging in terms of PM mass, composition and size ranges emitted from 
abrasion roads in non-exhaust emission sources than results from current studies. The amounts of PM (emission factors) created during abrasion of concrete surfaces for different types of vehicles are not known, what is more, a chemical composition of particles released during this process is also unknown. The constant concrete upgrades aimed at their mechanical improvement can lead to the presence of dangerous elements in the environment. The increasing production of silica, used in concrete mixtures, could be a good example. Thus, more extensive research to establish emission factors and chemical composition of PM emitted from currently used road pavements are necessary. Such studies should be conducted under laboratory, controlled conditions for defining emission factors and chemical composition of PM (depending on vehicle type, speed, environmental conditions). On the other hand, analyzing the impact of abrasion emission reflecting realistic conditions is also very important. Defining how such emissions quantitatively and qualitatively change the character of PM near roads is crucial as it allows researchers also to assess PM parameters determining the power and scale of its influence in the environment. Gathering such information will allow for the revision of forecasts and scripts of PM impact on the environment and human health.

Acknowledgments: The work was financed in the frame of the Statutory Studies conducted in the Faculty of Fire Safety Engineering, The Main School of Fire Service, Poland.

Author Contributions: All authors conceived and wrote the paper.

Conflicts of Interest: The authors declare no conflict of interest.

\section{References}

1. Buckeridge, D.L.; Glazier, R.; Harvey, B.J.; Escobar, M.; Amrhein, C.; Frank, J. Effect of motor vehicle emissions on respiratory health in an urban area. Environ. Health Perspect. 2002, 110, 293-300. [CrossRef] [PubMed]

2. Fan, Z.; Meng, Q.; Weisel, C.; Shalat, S.; Laumbach, R.; Ohman-Strickland, P.; Black, K.; Rodriguez, M.; Bonanno, L. Acute Short-Term Exposures to $\mathrm{PM}_{2.5}$ Generated by Vehicular Emissions and Cardiopulmonary Effects in Older Adults. Epidemiology 2006, 17, 213-214. [CrossRef]

3. Harrison, R.M.; Jones, A.M.; Lawrence, R.G. Major component composition of $\mathrm{PM}_{10}$ and $\mathrm{PM}_{2.5}$ from roadside and urban background sites. Atmos. Environ. 2004, 38, 4531-4538. [CrossRef]

4. Harrison, R.M.; Smith, D.J.T.; Luhana, L. Source Apportionment of Atmospheric Polycyclic Aromatic Hydrocarbons Collected from an Urban Location in Birmingham, U.K. Environ. Sci. Technol. 1996, 30, 825-832. [CrossRef]

5. Health Effects Institute. HEI Panel on the Health Effects of Traffic-Related Air Pollution: A Critical Review of the Literature on Emissions, Exposure, and Health Effects; HEI Special Report 17; Health Effects Institute: Boston, MA, USA, 2010.

6. Hueglin, C.; Gehrig, R.; Baltensperger, U.; Gysek, M.; Monn, C.; Vonmont, H. Chemical characterization of $\mathrm{PM}_{2.5}, \mathrm{PM}_{10}$ and coarse particles at urban, near-city and rural sites in Switzerland. Atmos. Environ. 2005, 39, 637-651. [CrossRef]

7. Karagulian, F.; Belis, C.A.; Dora, C.F.C.; Prüss-Ustün, A.M.; Bonjour, S.; Adair-Rohani, H.; Amann, M. Contributions to cities' ambient particulate matter (PM): A systematic review of local source contributions at global level. Atmos. Environ. 2015, 120, 475-483. [CrossRef]

8. Masiol, M.; Hofer, A.; Squizzato, S.; Piazza, R.; Rampazzo, G.; Pavoni, B. Carcinogenic and mutagenic risk associated to airborne particle-phase polycyclic aromatic hydrocarbons: A source apportionment. Atmos. Environ. 2012, 60, 375-382. [CrossRef]

9. Pant, P.; Harrison, R.M. Estimation of the contribution of road traffic emissions to particulate matter concentrations from field measurements: A review. Atmos. Environ. 2013, 77, 78-97. [CrossRef]

10. Rissler, J.; Swietlicki, E.; Bengtsson, A.; Boman, C.; Pagels, J.; Sandström, T.; Blomberg, A.; Löndahl, J. Experimental determination of deposition of diesel exhaust particles in the human respiratory tract. J. Aerosol Sci. 2012, 48, 18-33. [CrossRef]

11. Rogula-Kozłowska, W. Chemical composition and mass closure of ambient particulate matter at a crossroads and a highway in Katowice, Poland. Environ. Prot. Eng. 2015, 41, 15-29. 
12. Rogula-Kozłowska, W. Traffic-Generated Changes in the Chemical Characteristics of Size-Segregated Urban Aerosols. Bull. Environ. Contam. Toxicol. 2014, 93, 493-502. [CrossRef] [PubMed]

13. Rogula-Kozłowska, W.; Pastuszka, J.S.; Talik, E. Influence of Vehicular Traffic on Concentration and Particle Surface Composition of $\mathrm{PM}_{10}$ and $\mathrm{PM}_{2.5}$ in Zabrze, Poland. Pol. J. Environ. Stud. 2008, 17, 539-548.

14. Enroth, J.; Saarikoski, S.; Niemi, J.; Kousa, A.; Ježek, I.; Močnik, G.; Carbone, S.; Kuuluvainen, H.; Rönkkö, T.; Hillamo, R.; et al. Chemical and physical characterization of traffic particles in four different highway environments in the Helsinki metropolitan area. Atmos. Chem. Phys. 2016, 16, 5497-5512. [CrossRef]

15. Geller, M.D.; Ntziachristos, L.; Mamakos, A.; Samaras, Z.; Schmitz, D.A.; Froines, J.R.; Sioutas, C. Physicochemical and redox characteristics of particulate matter (PM) emitted from gasoline and diesel passenger cars. Atmos. Environ. 2006, 40, 6988-7004. [CrossRef]

16. Harrison, R.M.; Tilling, R.; Callén Romero, M.S.; Harrad, S.; Jarvis, K. A study of trace metals and polycyclic aromatic hydrocarbons in the roadside environment. Atmos. Environ. 2003, 37, 2391-2402. [CrossRef]

17. Mauderly, J.L. Toxicological and epidemiological evidence for health risks from inhaled engine emissions. Environ. Health Perspect. 1994, 102, 165-171. [CrossRef] [PubMed]

18. Pant, P.; Shi, Z.; Pope, F.D.; Harrison, R.M. Characterization of Traffic-Related Particulate Matter Emissions in a Road Tunnel in Birmingham, UK: Trace Metals and Organic Molecular Markers. Aerosol Air Qual. Res. 2017, 17, 117-130. [CrossRef]

19. Pastuszka, J.S.; Rogula-Kozłowska, W.; Zajusz-Zubek, E. Characterization of $\mathrm{PM}_{10}$ and $\mathrm{PM}_{2.5}$ and associated heavy metals at the crossroads and urban background site in Zabrze, Upper Silesia, Poland, during the smog episodes. Environ. Monit. Assess. 2010, 168, 613-627. [CrossRef] [PubMed]

20. Rogula-Kozłowska, W.; Kozielska, B.; Klejnowski, K. Concentration, Origin and Health Hazard from Fine Particle-Bound PAH at Three Characteristic Sites in Southern Poland. Arch. Environ. Contam. Toxicol. 2013, 91, 349-355. [CrossRef] [PubMed]

21. Rogula-Kopiec, P.; Kozielska, B.; Rogula-Kozłowska, W. Road Traffic Effects in Size-segregated Ambient Particle-bound PAHs. Int. J. Environ. Res. 2016, 10, 531-542.

22. Rogula-Kozłowska, W.; Rogula-Kopiec, P.; Klejnowski, K.; Blaszczyk, J. Influence of vehicular traffic on concentration and mass size distribution of two fractions of carbon in an urban area atmospheric aerosol. Rocz. Ochr. Sr. 2013, 15, 1623-1644.

23. Grigoratos, T.; Martini, G. Brake wear particle emissions: A review. Environ. Sci. Pollut. Res. 2015, 22, 2491-2504. [CrossRef] [PubMed]

24. Grigoratos, T.; Martini, G. Non-Exhaust Traffic Related Emissions. Brake and Tyre Wear PM. JRC Science and Policy Reports. Literature Review; European Commission Joint Research Centre Institute of Energy and Transport: Luxembourg, 2014.

25. Kumar, P.; Pirjola, L.; Ketzel, M.; Harrison, R.M. Nanoparticle emissions from 11 non-vehicle exhaust sources-A review. Atmos. Environ. 2013, 67, 252-277. [CrossRef]

26. Badyda, A.J.; Dabrowiecki, P.; Czechowski, P.O.; Majewski, G.; Doboszyńska, A. Traffic-Related Air Pollution and Respiratory Tract Efficiency. Adv. Exp. Med. Biol. 2014, 834, 31-38.

27. Badyda, A.J.; Dabrowiecki, P.; Czechowski, P.O.; Majewski, G. Risk of bronchi obstruction among non-smokers-Review of environmental factors affecting bronchoconstriction. Respir. Physiol. Neurobiol. 2014, 209, 39-46. [CrossRef] [PubMed]

28. De Kok, T.M.C.M.; Driece, H.A.L.; Hogervorst, J.G.F.; Briedé, J.J. Toxicological assessment of ambient and traffic-related particulate matter: A review of recent studies. Mutat. Res. 2006, 613, 103-122. [CrossRef] [PubMed]

29. Grynkiewicz Bylina, B.; Rakwic, B.; Pastuszka, J.S. Assessment of Exposure to Traffic-Related Aerosol and to Particle-Associated PAHs in Gliwice, Poland. Pol. J. Environ. Stud. 2005, 14, 117-123.

30. Schauer, J.J.; Lough, G.C.; Shafer, M.M.; Christensen, W.F.; Arndt, M.F.; Deminter, J.T.; Park, J.S. Characterization of metals emitted from motor vehicles. Res. Rep. Health Eff. Inst. 2006, 133, 77-88.

31. Geller, M.D.; Sardar, S.B.; Phuleria, H.; Fine, P.M.; Sioutas, C. Measurements of Particle Number and Mass Concentrations and Size Distributions in a Tunnel Environment. Environ. Sci. Technol. 2005, 39, 8653-8663. [CrossRef] [PubMed]

32. Kwak, J.-H.; Kim, H.; Lee, J.; Lee, S. Characterization of non-exhaust coarse and fine particles from on-road driving and laboratory measurements. Sci. Total Environ. 2013, 458-460, 273-282. [CrossRef] [PubMed] 
33. Thorpe, A.J.; Harrison, R.M. Sources and properties of non-exhaust particulate matter from road traffic: A review. Sci. Total Environ. 2008, 400, 270-282. [CrossRef] [PubMed]

34. Thorpe, A.J.; Harrison, R.M.; Boulter, P.G.; Mccrae, I.S. Estimation of particle resuspension source strength on a major London Road. Atmos. Environ. 2007, 41, 8007-8020. [CrossRef]

35. Warner, L.R.; Sokhi, R.; Luhana, L.; Boulter, P.G. Non-Exhaust Particle Emissions from Road Transport: A Literature Review. Unpublished Report PR/SE/213/00. 2001. Available online: http:/ /lat.eng.auth.gr/ particulates/old_website/eterg/files/PR_SE_ 1.PDF (accessed on 27 October 2017).

36. Bukowiecki, N.; Lienemann, P.; Hill, M.; Furger, M.; Richard, A.; Amato, F.; Prévôt, A.S.H.; Baltensperger, U.; Buchmann, B.; Gehrig, R. PM 10 emission factors for non-exhaust particles generated by road traffic in an urban street canyon and along a freeway in Switzerland. Atmos. Environ. 2010, 44, 2330-2340. [CrossRef]

37. Rogula-Kozłowska, W.; Pastuszka, J.S.; Talik, E. Właściwości aerozolu ze źródeł komunikacyjnych; IPIŚ PAN: Zabrze, Poland, 2011; Volume 80, p. 111.

38. Oyama, B.S.; Andrade, M.; Herckes, P.; Dusek, U.; Röckmann, T.; Holzinger, R. Chemical characterization of organic particulate matter from on-road traffic in São Paulo, Brazil. Atmos. Chem. Phys. 2016, 16, 14397-14408. [CrossRef]

39. Dziugieł, M.; Bogacki, M. Metodyka wyznaczania emisji niezorganizowanej pyłu do powietrza z dróg oraz eksploatacji składowisk w kopalni odkrywkowej surowców mineralnych. Przeglą Górniczy 2013, 12, 68-74. (In Polish)

40. The Scientific Basis of Street Cleaning Activities as Road Dust Mitigation Measure, Action B7. 2013. Available online: http:/ / airuse.eu/wp-content/uploads/2013/11/B7-3-ES_road-cleaning.pdf (accessed on 27 October 2017).

41. Ravensworth Underground Mine-Coal Mine Particulate Matter Control Best Management Practice Determination; Xstrata Coal: Zug, Switzerland, 1979.

42. Adamiec, E.; Jarosz-Krzemińska, E.; Wieszała, R. Heavy metals from non-exhaust vehicle emissions in urban and motorway road dusts. Environ. Monit. Assess. 2016, 188, 369. [CrossRef] [PubMed]

43. Pirjola, L.; Johansson, C.; Kupiainen, K.; Stojiljkovic, A.; Karlsson, H.; Hussein, T. Road Dust Emissions from Paved Roads Measured Using Different Mobile Systems. J. Air Waste Manag. 2010, 60, 1422-1433. [CrossRef]

44. Kupiainen, K.; Tervahattu, H.; Räisänen, M. Experimental studies about the impact of traction sand on urban road dust composition. Sci. Total Environ. 2003, 308, 175-184. [CrossRef]

45. Garg, B.D.; Cadle, S.H.; Mulawa, P.A.; Groblicki, P.J.; Laroo, C.; Parr, G.A. Brake Wear Particulate Matter Emissions. Environ. Sci. Technol. 2000, 34, 4463-4469. [CrossRef]

46. Hildemann, L.M.; Markowski, G.R.; Cass, G.R. Chemical composition of emissions from urban sources of fine organic aerosol. Environ. Sci. Technol. 1991, 25, 744-759. [CrossRef]

47. Iijima, A.; Sato, K.; Yano, K.; Tago, H.; Kato, M.; Kimura, H.; Furuta, N. Particle size and composition distribution analysis of automotive brake abrasion dusts for the evaluation of antimony sources of airborne particulate matter. Atmos. Environ. 2007, 41, 4908-4919. [CrossRef]

48. Kennedy, P.; Gadd, J. Preliminary Examination of Trace Elements in Tyres, Brake Pads, and Road Bitumen in New Zealand; Infrastructure Auckland: Auckland, New Zealand, 2003.

49. Kennedy, P.; Gadd, J.; Moncrieff, I. Emission Factors for Contaminants Released by Motor Vehicles in New Zealand; Infrastructure Auckland: Auckland, New Zealand, 2002.

50. Legret, M.; Pagotto, C. Evaluation of pollutant loadings in the runoff waters from a major rural highway. Sci. Total Environ. 1999, 235, 143-150. [CrossRef]

51. Westerlund, K.G.; Johansson, C. Emission of Metals and Particulate Matter Due to Wear of Brake Linings in Stockholm. Air Pollut. 2002, 10, 793-802.

52. Dongarrà, G.; Manno, E.; Varrica, D. Possible markers of traffic-related emissions. Environ. Monit. Assess. 2009, 154, 117-125. [CrossRef] [PubMed]

53. Ingo, G.M.; D’Uffizi, M.; Falso, G.; Bultrini, G.; Padeletti, G. Thermal and microchemical investigation of automotive brake pad wear residues. Thermochim. Acta 2004, 418, 61-68. [CrossRef]

54. Przybek, P. Materiały Malarskie—Pomoc Dydaktyczna. 2004. Available online: http://bianda.cba.pl/tppch/ sload/materialy_malarskie.pdf (accessed on 9 August 2017).

55. Harrison, R.M.; Hester, R.E. Environmental Impacts of Road Vehicles: Past, Present and Future; Royal Society of Chemistry: London, UK, 2017. 
56. Harrison, R.M.; Jones, A.M.; Barrowcliffe, R. Field study of the influence of meteorological factors and traffic volumes upon suspended particle mass at urban roadside sites of differing geometries. Atmos. Environ. 2004, 38, 6361-6369. [CrossRef]

57. Amato, F.; Schaap, M.; Denier van der Gon, H.A.C.; Pandolfi, M.; Alastuey, A.; Keuken, M.; Querol, X. Effect of rain events on the mobility of road dust load in two Dutch and Spanish roads. Atmos. Environ. 2012, 62, 352-358. [CrossRef]

58. Olszowski, T. Changes in $\mathrm{PM}_{10}$ concentration due to large-scale rainfall. Arab. J. Geosci. 2016, 9, 160. [CrossRef]

59. Amato, F.; Karanasiou, A.; Cordoba, P.; Alastuey, A.; Moreno, T.; Lucarelli, F.; Nava, S.; Calzolai, G.; Querol, X. Effects of Road Dust Suppressants on PM Levels in a Mediterranean Urban Area. Environ. Sci. Technol. 2014, 48, 8069-8077. [CrossRef] [PubMed]

60. Rogula-Kozłowska, W.; Błaszczak, B.; Szopa, S.; Klejnowski, K.; Sówka, I.; Zwoździak, A.; Jabłońska, M.; Mathews, B. PM 2.5 in the central part of Upper Silesia, Poland: Concentrations, elemental composition, and mobility of components. Environ. Monit. Assess. 2013, 185, 581-601. [CrossRef] [PubMed]

61. Rogula-Kozłowska, W.; Klejnowski, K.; Rogula-Kopiec, P.; Ośródka, L.; Krajny, E.; Błaszczak, B.; Mathews, B. Spatial and seasonal variability of the mass concentration and chemical composition of $\mathrm{PM}_{2.5}$ in Poland. Air Qual. Atmos. Health 2014, 7, 41-58. [CrossRef] [PubMed]

62. Rogula-Kozłowska, W.; Majewski, G.; Czechowski, P.O. The size distribution and origin of elements bound to ambient particles: A case study of a Polish urban area. Environ. Monit. Assess. 2015, 187, 240. [CrossRef] [PubMed]

63. Klejnowski, K.; Rogula-Kozłowska, W.; Łusiak, T. Some metals and polycyclic aromatic hydrocarbons in fugitive $\mathrm{PM}_{10}$ emissions from the coking process. Environ. Prot. Eng. 2012, 38, 59-71.

64. Konieczyński, J.; Zajusz-Zubek, E. Distribution of selected trace elements in dust containment and flue gas desulphurisation products from coal-fired power plants. Arch. Environ. Prot. 2011, 37, 3-14.

65. Kozielska, B.; Konieczyński, J. Polycyclic aromatic hydrocarbons in dust emitted from stoker-fired boilers. Environ. Technol. 2007, 28, 895-903. [CrossRef] [PubMed]

66. Kozielska, B.; Konieczyński, J. Polycyclic aromatic hydrocarbons in particulate matter emitted from coke oven battery. Fuel 2015, 144, 327-334. [CrossRef]

67. Rogula-Kopiec, P.; Rogula-Kozłowska, W.; Kozielska, B.; Sówka, I. PAH Concentrations Inside a Wood Processing Plant and the Indoor Effects of Outdoor Industrial Emissions. Pol. J. Environ. Stud. 2015, 24. [CrossRef]

68. Zajusz-Zubek, E.; Konieczyński, J. Dynamics of trace elements release in a coal pyrolysis process. Fuel 2003, 82, 1281-1290. [CrossRef]

69. Dahl, A.; Gharibi, A.; Swietlicki, E.; Gudmundsson, A.; Bohgard, M.; Ljungman, A.; Blomgvist, G.; Gustafsson, M. Traffic-generated emissions of ultrafine particles from pavement-tire interface. Atmos. Environ. 2006, 40, 1314-1323. [CrossRef]

70. Amato, F.; Pandolfi, M.; Moreno, T.; Furger, M.; Pey, J.; Alastuey, A.; Bukowiecki, N.; Prevot, A.S.H.; Baltensperger, U.; Querol, X. Sources and variability of inhalable road dust particles in three European cities. Atmos. Environ. 2011, 45, 6777-6787. [CrossRef]

71. Amato, F.; Viana, M.; Richard, A.; Furger, M.; Prévôt, A.S.H.; Nava, S.; Lucarelli, F.; Bukowiecki, N.; Alastuey, A.; Reche, C.; et al. Size and time-resolved roadside enrichment of atmospheric particulate pollutants. Atmos. Chem. Phys. 2011, 11, 2917-2931. [CrossRef]

72. Duong, T.T.T.; Lee, B.K. Determining contamination level of heavy metals in road dust from busy traffic areas with different characteristics. J. Environ. Manag. 2011, 92, 554-562. [CrossRef] [PubMed]

73. Omstedt, G.; Bringfelt, B.; Johansson, C. A model for vehicle-induced non-tailpipe emissions of particles along Swedish roads. Atmos. Environ. 2005, 39, 6088-6097. [CrossRef]

74. Adachi, K.; Tainosho, Y. Characterization of heavy metal particles embedded in tire dust. Environ. Int. 2004, 30, 1009-1017. [CrossRef] [PubMed]

75. Denier van der Gon, H.A.C.; Gerlofs-Nijland, M.E.; Gehrig, R.; Gustafsson, M.; Janssen, N.; Harrison, R.M.; Hulskotte, J.; Johansson, C.; Jozwicka, M.; Keuken, M.; et al. The Policy Relevance of Wear Emissions from Road Transport, Now and in the Future-An International Workshop Report and Consensus Statement. J. Air Waste Manag. 2013, 63, 136-149. [CrossRef] 
76. Hjortenkrans, D.S.T.; Bergbäck, B.G.; Häggerud, A.V. Metal Emissions from Brake Linings and Tires: Case Studies of Stockholm, Sweden 1995/1998 and 2005. Environ. Sci. Technol. 2007, 41, 5224-5230. [CrossRef] [PubMed]

77. Johansson, C.; Norman, M.; Burman, L. Road traffic emission factors for heavy metals. Atmos. Environ. 2009, 43, 4681-4688. [CrossRef]

78. Querol, X.; Alastuey, A.; Ruiz, C.R.; Artinano, B.; Hansson, H.C.; Harrison, R.M.; Buringh, E.; ten Brink, H.M.; Lutz, M.; Bruckmann, P.; et al. Speciation and origin of $\mathrm{PM}_{10}$ and $\mathrm{PM}_{2.5}$ in selected European cities. Atmos. Environ. 2004, 38, 6547-6555. [CrossRef]

79. Lenschow, P.; Abraham, H.J.; Kutzner, K.; Lutz, M.; Preuß, J.D.; Reichenbacher, W. Some ideas about the sources of $\mathrm{PM}_{10}$. Atmos. Environ. 2001, 35, 23-33. [CrossRef]

80. Amato, F.; Karanasiou, A.; Moreno, T.; Alastuey, A.; Orza, J.A.G.; Lumbreras, J.; Borge, R.; Boldo, E.; Linares, C.; Querol, X. Emission factors from road dust resuspension in a Mediterranean freeway. Atmos. Environ. 2012, 61, 580-587. [CrossRef]

81. Harrison, R.M.; Beddows, D.C.S.; Dall'Osto, M. PMF Analysis of Wide-Range Particle Size Spectra Collected on a Major Highway. Environ. Sci. Technol. 2011, 45, 5522-5528. [CrossRef] [PubMed]

82. Harrison, R.M.; Jones, A.M.; Gietl, J.; Yin, J.; Green, D.C. Estimation of the Contributions of Brake Dust, Tire Wear, and Resuspension to Nonexhaust Traffic Particles Derived from Atmospheric Measurements. Environ. Sci. Technol. 2012, 46, 6523-6529. [CrossRef] [PubMed]

83. Kuhlbusch, T.A.J.; John, A.C.; Quass, U. Sources and source contributions to fine particles. Biomarkers 2009, 14, 23-28. [CrossRef] [PubMed]

84. Friedlander, S.K. The characterization of aerosols distributed with respect to size and chemical composition-I. J. Aerosol Sci. 1970, 1, 295-307. [CrossRef]

85. Friedlander, S.K. The characterization of aerosols distributed with respect to size and chemical composition-II. J. Aerosol Sci. 1971, 2, 331-340. [CrossRef]

86. Hinds, W.C. Aerosol Technology: Properties, Behavior, and Measurement of Airborne Particles, 2nd ed.; John Wiley and Sons: New York, NY, USA, 1998.

87. Abu-Allaban, M.; Gillies, J.A.; Gertler, A.W.; Clayton, R.; Profitt, D. Tailpipe, resuspended road dust, and brake-wear emission factors from on-road vehicles. Atmos. Environ. 2003, 37, 5283-5293. [CrossRef]

88. Kam, W.; Liacos, J.W.; Schauer, J.J.; Delfino, R.J.; Sioutas, C. Size-segregated composition of particulate matter (PM) in major roadways and surface streets. Atmos. Environ. 2012, 55, 90-97. [CrossRef]

89. Tervahattu, H.; Kupiainen, K.J.; Räisänen, M.; Makela, T.; Hillamo, R. Generation of urban road dust from anti-skid and asphalt concrete aggregates. J. Hazard. Mater. 2006, 132, 39-46. [CrossRef] [PubMed]

90. Keuken, M.; Denier van der Gon, H.; van der Valk, K. Non-exhaust emissions of PM and the efficiency of emission reduction by road sweeping and washing in the Netherlands. Sci. Total Environ. 2010, 408, 4591-4599. [CrossRef] [PubMed]

91. Forsberg, B.; Hansson, H.C.; Johansson, C.; Areskoug, H.; Persson, K.; Järvholm, B. Comparative Health Impact Assessment of Local and Regional Particulate Air Pollutants in Scandinavia. Ambio 2005, 34, 11-19. [CrossRef] [PubMed]

92. Von Uexküll, O.; Skerfving, S.; Doyle, R.; Braungart, M. Antimony in brake pads-a carcinogenic component? J. Clean. Prod. 2005, 13, 19-31. [CrossRef]

93. Woodside, A.R. Aggregates and Fillers in Asphalt Surfacings: A Guide to Asphalt Surfacings and Treatments Used for the Surface Course of Road Pavements; The National Academies of Sciences, Engineering, and Medicine: Washington, DC, USA, 1998.

94. Watson, J.G.; Chow, J.C. Receptormodels for source apportionment of suspended particles. In Introduction to Environmental Forensics, 2nd ed.; Academic Press: New York, NY, USA, 2007; Volume 2, pp. 279-316.

95. Chow, J.C. Measurement Methods to Determine Compliance with Ambient Air Quality Standards for Suspended Particles. J. Air Waste Manag. 1995, 45, 320-382. [CrossRef]

96. Lawrence, S.; Sokhi, R.; Ravindra, K.; Mao, H.; Prain, H.D.; Bull, I.D. Source apportionment of traffic emissions of particulate matter using tunnel measurements. Atmos. Environ. 2013, 77, 548-557. [CrossRef]

97. Rybak, J. Accumulation of Major and Trace Elements in Spider Webs. Water Air Soil Pollut. 2015, $226,105$. [CrossRef] [PubMed]

98. Richter, P.; Griño, P.; Ahumada, I.; Giordano, A. Total element concentration and chemical fractionation in airborne particulate matter from Santiago, Chile. Atmos. Environ. 2007, 41, 6729-6738. [CrossRef] 
99. Gómez, B.; Gómez, M.; Sanchez, J.L.; Fernandez, R.; Palacios, M.A. Platinum and rhodium distribution in airborne particulate matter and road dust. Sci. Total Environ. 2001, 269, 131-144. [CrossRef]

100. Heck, R.M.; Farrauto, R.J. Automobile exhaust catalysts. Appl. Catal. A 2001, 221, 443-457. [CrossRef]

101. Virtanen, A.; Keskinen, J.; Ristimäki, J.; Rönkkö, T.; Vaaraslahti, K. Reducing Particulate Emissions in Traffic and Transport; Views and Conclusions from the FINE Particles-Technology. Environment and Health Technology Programme; Tekes: Tampere, Finland, 2006.

102. AQEG. Particulate Matter in the United Kingdom; DEFRA: London, UK, 2005.

103. Fauser, P.; Tjell, J.C.; Bjerg, P.L. Particulate air Pollution, with Emphasis on Traffic Generated Aerosols; Riso National Laboratory and Technikal University of Denmark: Roskilde, Denmark, 1999.

104. Gadd, J.; Kennedy, P. Preliminary Examination of Organic Compounds present in Tyres, Brake Pads, and Road Bitumen in New Zealand, rev. ed.; Prepared for Ministry of Transport; Infrastructure Auckland: Auckland, New Zealand, 2003.

105. Boulter, P. A review of Emission Factors and Models for Road Vehicle Non-Exhaust Particulate Matter; Report Prepared for DEFRA; TRL: Wokingham, UK, 2005.

106. Lindgren, A. Asphalt wear and pollution transport. Sci. Total Environ. 1996, 189-190, 281-286. [CrossRef]

107. Piłat, J.; Radziszewski, P. Nawierzchnie Asfaltowe; Wydawnictwa Komunikacji I Łaczności: Warsaw, Poland, 2007.

108. Dodds, C.J.; Robson, J.D. The description of road surface roughness. J. Sound Vib. 1973, 31, 1751-1783. [CrossRef]

109. Robson, J.D. Road surface description and vehicle response. Int. J. Veh. Des. 1979, 1. [CrossRef]

110. Katalog Typowych Konstrukcji Nawierzchni Podatnych I Półsztywnych. GDDKiA: Warsaw, Poland, 2014. Available online: https: / / www.gddkia.gov.pl/userfiles/articles/p/prace-naukowo-badawcze-po-roku2_3432/Weryfikacja\%20KataloguTNPiP_Etap4_final_11\%2003\%202013.pdf (accessed on 11 March 2013).

111. Katalog Typowych Konstrukcji Nawierzchni Sztywnych. GDDKiA: Warsaw, Poland, 2014. Available online: https:/ / www.gddkia.gov.pl/userfiles/articles/z/zarzadzenia-generalnego-dyrektor_ 13901/zarzadzenie\%2030\%20zalacznik.pdf (accessed on 16 June 2016).

112. Gillies, J.A.; Etyemezian, V.; Kuhns, H.; Nikolic, D.; Gillette, D.A. Effect of vehicle characteristics on unpaved road dust emissions. Atmos. Environ. 2005, 39, 2341-2347. [CrossRef]

113. Gillies, J.A.; Watson, J.G.; Rogers, C.F.; DuBois, D.; Chow, J.C.; Langston, R.; Sweet, J. Long-Term Efficiencies of Dust Suppressants to Reduce $\mathrm{PM}_{10}$ Emissions from Unpaved Roads. J. Air Waste Manag. 1999, 49, 31-36. [CrossRef] [PubMed]

114. Watson, J.G.; Rogers, C.F.; Chow, J.C.; DuBois, D.; Gillies, J.A.; Derby, J.; Moosmüller, H. Effectiveness Demonstration of Fugitive Dust Control Methods for Public Unpaved Roads and Unpaved Shoulders on Paved Roads; Final Report DRI; DRI: Reno, NV, USA, 1996.

115. Christoforidis, A.; Stamatis, N. Heavy metal contamination in street dust and roadside along the main national road in Kavala's region, Greece. Geoderma 2009, 151, 257-263. [CrossRef]

116. Forman, R.T.T.; Sperling, D.; Bissonette, J.A.; Clevenger, A.P.; Cutshall, C.D.; Dale, V.H.; Fahrig, L.; France, R.L.; Goldman, C.R.; Heanue, K.; et al. Road Ecology. Science and Solutions; Island Press: Washington, DC, USA, 2013.

117. Kozłowski, W.; Surowiecki, A. Kierunki rozwoju konstrukcji nawierzchni dróg wiejskich. Problemy Inżynierii Rolniczej 2011, 1, 173-183.

118. Nicholls, J. Asphalt Surfacings: A Guide to Asphalt Surfacings and Treatments Used for the Surface Course of Road Pavements; Transport Research Laboratory, E\&FN SPON An Imprint of Routledge: London, UK, 1998.

119. NIOSH. Hazard Review: Health Effects of Occupational Exposure to Asphalt; Department of Health and Human Services [DHHS] and NIOSH: Cincinnati, OH, USA, 2000.

120. Szruba, M. Nawierzchnie betonowe. Nowoczesne Budownictwo Inżynieryjne 2016, 10, 56-58.

121. Yongming, H.; Peixuan, D.; Junji, C.; Posmentier, E.S. Multivariate analysis of heavy metal contamination in urban dusts of Xi'an, Central China. Sci. Total Environ. 2006, 355, 176-186. [CrossRef] [PubMed]

122. Allen, J.O.; Alexandrova, O.; Kaloush, K.E. Tire Wear Emissions for Asphalt Rubber and Portland Cement Concrete Pavement Surfaces; Report Submitted to Arizona Department of Transportation; Arizona State University: Tempe, AZ, USA, 2006.

123. Gustafsson, M.; Blomqvist, G.; Gudmundsson, A.; Dahl, A.; Swietlicki, E.; Bohgard, M.; Lindbom, J.; Ljungman, A. Properties and toxicological effects of particles from the interaction between tyres, road pavement and winter traction material. Sci. Total Environ. 2008, 393, 226-240. [CrossRef] [PubMed] 
124. Hussein, T.; Johansson, C.; Karlsson, H.; Hansson, H.C. Factors affecting non-tailpipe aerosol particle emissions from paved roads: On-road measurements in Stockholm, Sweden. Atmos. Environ. 2008, 42, 688-702. [CrossRef]

125. Kupiainen, K.J.; Tervahattu, H.; Räisänen, M.; Mäkelä, T.; Aurela, M.; Hillamo, R. Size and Composition of Airborne Particles from Pavement Wear, Tires, and Traction Sanding. Environ. Sci. Technol. 2005, 39, 699-706. [CrossRef] [PubMed]

126. Schaap, M.; Manders, A.M.M.; Hendriks, E.C.J.; Cnossen, J.M.; Segers, A.J.S.; Denier van der Gon, H.A.C.; Jozwicka, M.; Sauter, F.; Velders, G.; Matthijsen, J.; et al. Regional Modelling of PM10 over the Netherlands; Technical Report 500099008; Netherlands Environmental Assessment Agency, (PBL): Bilthoven, The Netherlands, 2009.

127. Sjodin, A.; Ferm, M.; Bjork, A.; Rahmberg, M.; Gudmundsson, A.; Swietlickli, E.; Johansson, C.; Gustafsson, M.; Blomqvist, G. Wear Particles from Road Traffic: A Field, Laboratory and Modelling Study; IVL Report B1830; IVL: Göteborg, Sweden, 2010.

128. Ferm, M.; Sjöberg, K. Concentrations and emission factors for $\mathrm{PM}_{2.5}$ and $\mathrm{PM}_{10}$ from road traffic in Sweden. Atmos. Environ. 2015, 119, 211-219. [CrossRef]

129. Gustafsson, M.; Blomqvist, G.; Gudmundsson, A.; Dahl, A.; Jonsson, P.; Swietlicki, E. Factors influencing $\mathrm{PM}_{10}$ emissions from road pavement wear. Atmos. Environ. 2009, 43, 4699-4702. [CrossRef]

130. Gehrig, R.; Zeyer, K.; Bukowiecki, N.; Lienemann, P.; Poulikakos, L.D.; Furger, M.; Buchmann, B. Mobile load simulators-A tool to distinguish between the emissions due to abrasion and resuspension of $\mathrm{PM}_{10}$ from road surfaces. Atmos. Environ. 2010, 44, 4937-4943. [CrossRef]

(C) 2018 by the authors. Licensee MDPI, Basel, Switzerland. This article is an open access article distributed under the terms and conditions of the Creative Commons Attribution (CC BY) license (http:/ / creativecommons.org/licenses/by/4.0/). 